\title{
Transforming forestry education for better job prospects
}

\author{
Ayyanadar Arunachalam* and Latika Pandey
}

Every year, nearly 1500 graduates in B Sc (Forestry) pass out from different colleges/universities across India, who are well trained in the sustainable management and utilization of forest resources in the country. However, the challenge is the unavailability of provisions for their direct recruitment in the field of forestry, specially in the State and Central Forest Services, when they are getting education which is equivalent to the curricula of training courses of the Indian Forest Service officers. When the nation is deeply devoted to improving its forest cover in order to fulfil the commitment given to UNFCCC of reducing the $\mathrm{CO}_{2}$ emission and enhancing carbon sequestration for climate change mitigation along with extracting more from available renewable resources, proper management and sustainable utilization of forest resources is inevitable. So, the potential of these forestry graduates can be well utilized by enabling some structural reforms in the existing recruitment policy of the State and Central Forest Services by providing them job reservation and/or preference in forest and allied sectors, which will also justify the professional education and training provided to them.

Keywords: Education, employment, forestry, forest resources, sustainable management.

\section{History and governance regime}

THE history of forestry education in India started way back in 1878, when a college for forest rangers was started at Dehradun for imparting a two-year professional forestry training programme, as direct recruitment for the gazetted posts was limited to only Europeans who were trained from Germany, France and England. Recruitment for the Provincial Gazetted Services was opened in 1912 to Indians and the Forestry Research Institute (FRI) established in 1906 at Dehradun prepared a professional forestry course of high standard for the officers. This was known as the Provincial Forestry Course ${ }^{1}$.

Currently, the Indian Council of Forestry Research and Education (ICFRE) is the apex body, steering forestry research and education in the country. ICFRE is an autonomous organization established in 1987 under the aegis of the Ministry of Environment, Forest and Climate Change (MoEFCC), Government of India (GoI), with its headquarters at Dehradun. The major functions of the Council include research in forestry, technology transfer and to impart forestry education through its nine research

Ayyanadar Arunachalam is in the Indian Council of Agricultural Research, Krishi Bhawan, New Delhi 110 001, India; Latika Pandey is in the NMSHE-Task Force on Himalayan Agriculture, Natural Resource Management Division, Indian Council of Agricultural Research, New Delhi 110 002, India.

*For correspondence. (e-mail: arun.icar@nic.in) institutes and four advanced centres which are located at Dehradun, Shimla, Ranchi, Jorhat, Jabalpur, Jodhpur, Bengaluru, Coimbatore, Allahabad, Chhindwara, Aizawl, Hyderabad and Agartala ${ }^{2}$. FRI was granted the status of a deemed university in 1991, on the recommendations of the University Grant Commission (UGC), Ministry of Human Resource Development, GoI.

In 1986, the National Commission on Agriculture (NCA), under the Ministry of Agriculture, GoI proposed the initiation of forestry education in India for better conservation of forests, natural resources management and protection of the environment, which was envisaged in the third National Forest Policy of India-1988. Preceding this, the Indian Council of Agricultural Research (ICAR), established in 1929 and then the apex body that was governing forestry education as well, started undergraduate (UG) degree programme in forestry in 1985, in about 14 State Agricultural Universities (SAUs) across the country. Some of the traditional universities have also started this degree programme along with postgraduate $(\mathrm{PG})$ courses with different specializations (e.g. forest genetic resources, forest products and utilization, etc.). Nonetheless, for any admission to B Sc (Forestry), the aspirants are to qualify the exam conducted by ICAR-AIEEA (AllIndia Entrance Examination for Admission) or a statelevel entrance test, as the case may be, for admission to agricultural universities only. The traditional universities have their own admission procedures. On an average, around 1500 forestry graduates pass out each year from 
different states of India ${ }^{3}$. This programme has curricula equivalent to the standard syllabus of training courses of the Indian Forest Service (IFS) officers provided at the Indira Gandhi National Forest Academy (IGNFA) in Dehradun. The UG degree programme in forestry, like any other agriculture subject, is of four years duration and students are taught about forest ecology, silviculture, silvicultural systems, agroforestry, social forestry, wood science and technology, non-timber forest products (NTFPs), forest regeneration and forest management, wildlife, forest mensuration, statistics, etc. In the final year, fieldwork for one year under the Rural Forestry Work Experience (RFWE) programme, similar to the Rural Agriculture Work Experience (RAWE) programme of B Sc Agriculture is also included in the programme. The curricula enable a student to be a professional forester and the degree is awarded to eligible candidates by their respective agricultural university, guided by ICAR norms. Currently, there are around 35 universities which provide B Sc degree in forestry, around 20 which provide $\mathrm{M} \mathrm{Sc}$ degree and very few with $\mathrm{Ph} \mathrm{D}$ programmes, where the student intake also differs according to the institute or university. The ICFRE prepared a national model syllabus for forestry education and circulated it among universities/institutes for possible adoption, allowing a deviation of $25 \%$ to accommodate locally relevant forestbased curricula. A similar guideline has also been issued by ICAR. At present, both the Councils continue to support the forestry establishments with developmental grants to strengthen forestry education.

\section{Employability of forestry graduates}

When it comes to the employability of students with forestry education, the challenges are many. More than $90 \%$ of forest area in the country is Government-owned; hence, the overall management and utilization of forest resources is exclusively done by the Forest Department. To get inducted in the IFS, one has to be a science graduate, not necessarily a forestry graduate. Eventually, the selected officers who clear the national-level examination and are scrutinized by the Union Public Service Commission (UPSC), undergo a two-year professional training course in forestry in IGNFA. This tradition is continuing ever since the creation of the Service in 1938, even before the introduction of formal forestry education in the country. Currently, there are more than 2700 IFS officers serving the 31 Forest Departments managing a total of 1341 forest divisions in the States and Union Territories ${ }^{4}$, and many of them work in Ministries and other institutions as well ${ }^{5}$. As forest is a national asset, role of the private sector in forest management, unlike many European countries, is bleak under the existing provisions of law. As a result, job opportunities are less for forestry graduates in their own field compared to other fields like agriculture and horticulture, or veterinary, although all of them have been declared as professional courses by the ICAR in 2016. Nonetheless, there are overlapping opportunities with allied sectors like agriculture officers in banks, block horticulture officers, seed departments, tea estates, etc. In such cases, the utility of forest education becomes negligible. Hence the forestry graduates are forced to change their field of specialization after graduation to any other allied fields like environmental sciences, agriculture, horticulture, genetics and plant breeding, etc. which have better scope in terms of job opportunities. The reason behind fewer jobs in forestry may also be attributed to the low contribution of forestry sector (around 2\%) in the country's GDP, which risks a career in such an under-performing sector (Box 1).

The scenario of unemployment does not change even after obtaining a PG degree in this field. As far as forestry-based jobs are concerned, forestry education has direct applications in state forest services like forester, ranger, forest conservator, Divisional Forest Officer, etc. for which there are no uniform policies or recruitment, rules across states. Thus, higher education in forestry enables a candidate to take up research in educational and research institutions, or as field professional in seed and nursery companies, managerial positions in land management agencies, technical positions in plant health inspection services or plant resources laboratories, or a suitable adjunct position in eco-parks, biotechnology firms, paper and pulp industry, biological supply houses, chemical industry, biofuel industries, gums and resin industries, tea estates, etc. It is an irony that in the field of forestry, the number of jobs in the private sector is much less compared to the government sector.

There are only a few companies in India which require forestry graduates to work with them, such as paper and pulp industries, agriculture and plantation-related companies, NGOs, matchbox industries, Kattha and Cutch industry, sandalwood industry, composite wood industries, etc.

Saw mills prospered in the early 1970s, but with Supreme Court's ban on timber felling has affected the livelihood security of individuals involved in the sector ${ }^{6}$. Bamboo-based industries thrive well in antiques and handicrafts, but with the declaration of bamboo as an agriculture crop, opportunities for the foresters are being challenged. Trade of any forest product is also banned under law, thus limiting the survival fitness of a forestry graduate, professionally. Under such circumstances, many forestry graduates go abroad for a PG or research degree, and enter academia.

Forests are an integral part of the Indian society, as the importance of forests is well depicted historically in our epics like the Ramayana and the Arthashastra. It was as early as the 3rd century, the King Ashoka brought in laws prohibiting killing of animals and also set up facilities like water holes and hospitals for them. In this way, protection and management of forest resources have always 
Box 1. Employment opportunities for forestry graduates in India

In 2010, forestry students of the Forest College at Mettuppalayam, Tamil Nadu, petitioned the then Chief Minister in order to get reservation in direct recruitment of range officers in state forest services. The Principal Chief Conservator of Forests recommended $25 \%$ reservation of forestry graduates in direct recruitment of range officers. However, Tamil Nadu government overlooked this in successive years. As a result, the students demanded $100 \%$ reservation in the recruitment of forest rangers and direct recruitment to fulfil the scientific and management aspects. They argued that B Sc Forestry students should be considered for jobs in National Bamboo Mission, watershed projects, wasteland development projects, as managers and technical officers in the forestbased corporations such as TANTEA, Arasur Rubber Corporation, TNPPL, TAFCORN and also in the Tamil Nadu Forest Research Institute, Kolapakkam, in the same way as students of agriculture, horticulture, fisheries, etc. are preferred in their fields. Today, the state provides $50 \%$ reservation to the forestry graduates ${ }^{13}$.

In Odisha, forestry students of Odisha University of Agriculture and Technology (OUAT) demanded recruitment in the State Forest Departments by protesting on World Forestry Day (21 March 2012). They argued that B Sc Forestry degree should be made the minimum qualification for recruitment in the range officer cadre. They appealed for $100 \%$ reservation for forestry graduates for recruitment in the range office cadre, $50 \%$ reservation for the post of Assistant Conservator of Forests and immediate recruitment as forest ranger officers against onethird backlog vacancy since 1994. R. K. Patnaik, the then Dean, College of Forestry (OUAT), argued that even the National Forest Policy (1988) has recommended that forestry graduates be given preference in the recruitment range officers, IFS and Odisha Forest Services, and that the National Forest Commission has also recommended that range officers must be graduates with B Sc Forestry background from the SAUs. After all these struggles, currently, Odisha provides $50 \%$ reservation to forestry graduates in the recruitment of range officers ${ }^{14}$.

In 2016, forestry students of Akola and Dhapoli in Maharashtra undertook a hunger strike against the state government in order to seek changes in the recruitment policy of the Forest Department and wanted full reservation for forestry students in state forestry services. Around 64 students pass out from these colleges in Maharashtra, and most of the 2500 forestry graduates in the state were unemployed and over-aged. Hence they demanded changes in the recruitment policy of the state government and reservation in the post of forest rangers $^{15}$.

There are some states which recognize the significance of forestry education and provide reservation to forestry graduates in State Forest Departments, e.g. Himachal Pradesh and Haryana (70\%) reservation, Kerala $(25 \%)$, Karnataka $(75 \%)$, Jammu and Kashmir $(100 \%)^{20}$. The sad plight is that such efforts are not implemented country-wide ${ }^{3}$.

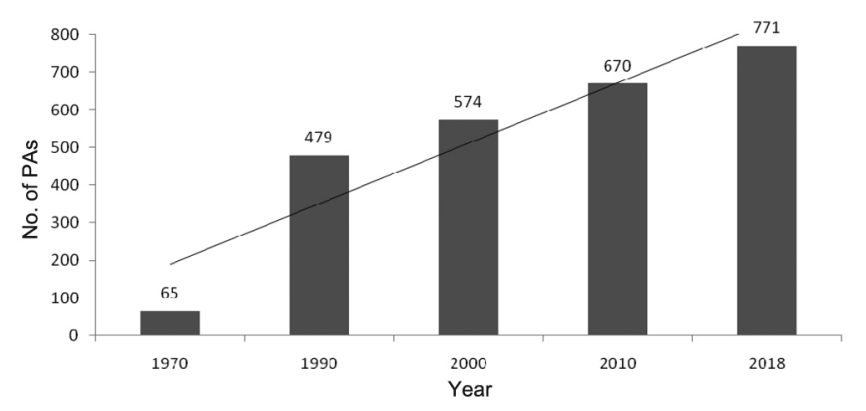

Figure 1. Number of protected areas (PAs) in India since 1970 (refs $11,12)$.

been embedded in the Indian culture, and sensitivity towards the ecosystem and its services. During the 20th century, the first national park in India (Jim Corbett National Park, erstwhile Hailey National Park) was established in 1936, after which the trend has been on the increase (Figure 1), indicating PAN-India awareness and efforts of the Government to secure forest resources by law, particularly the National Forest Policy 1988. For instance, the coverage of land under protected areas

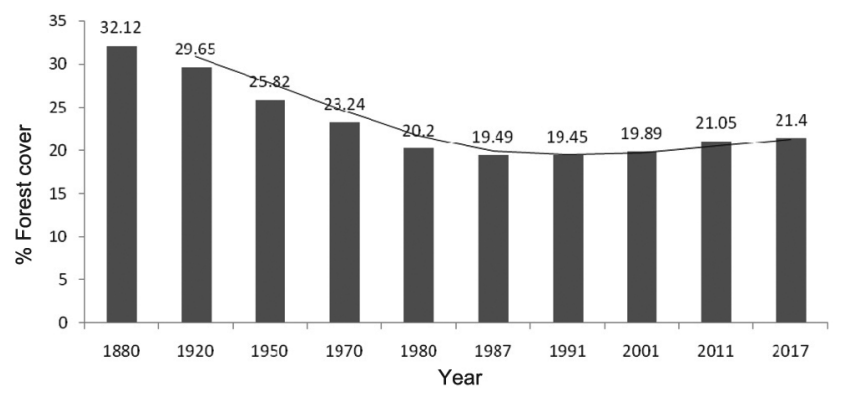

Figure 2. Percentage of forest cover in India since 1880 (refs 8-10).

(PAs) in India has risen by $0.5-5 \%$ of the land mass from 1969 to 2001 (ref. 7). While analysing the forest cover change in the country, the trend was found to be on the increase only after 1990s (Figure 2).

\section{Promoting forestry}

Recognizing the importance of forests in poverty alleviation, the government implemented industrial forestry, 
Table 1. Strength, weakness, opportunity and challenge analysis of forestry education in India

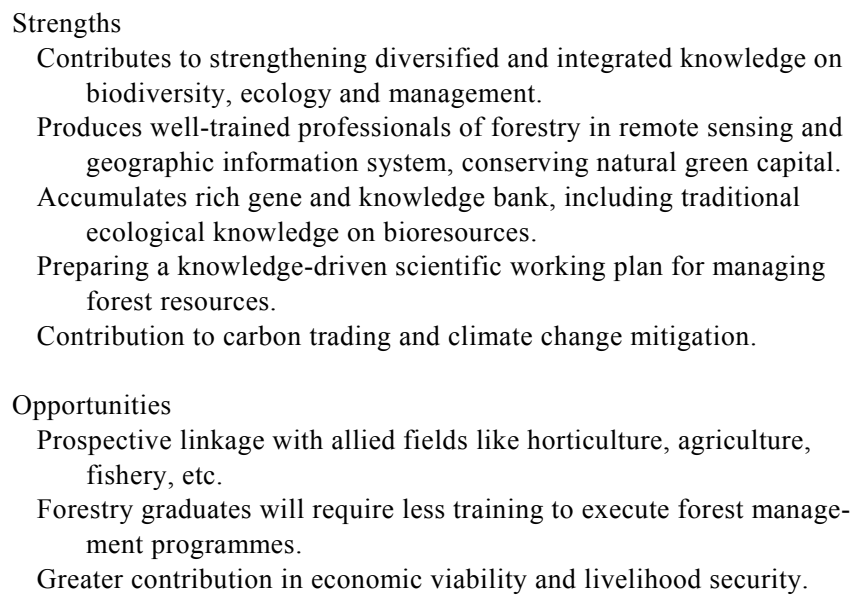

Contributes to strengthening diversified and integrated knowledge on biodiversity, ecology and management.

Produces well-trained professionals of forestry in remote sensing and geographic information system, conserving natural green capital.

Accumulates rich gene and knowledge bank, including traditional ecological knowledge on bioresources.

Preparing a knowledge-driven scientific working plan for managing forest resources.

Contribution to carbon trading and climate change mitigation.

Opportunities

Prospective linkage with allied fields like horticulture, agriculture, fishery, etc.

Forestry graduates will require less training to execute forest management programmes

Greater contribution in economic viability and livelihood security.

\section{Weaknesses}

Lack of funds to promote forestry education.

No preference/reservation to forestry graduates in jobs.

Lack of proper recruitment policy.

Lack of focused government schemes to promote forestry.

Prohibition of cultivation and cutting of many commercially important trees.

Lack of institutions for incubating forestry graduates towards entrepreneurship.

Less contribution of forestry sector (around 2\%) in the country's GDP.

Challenges

Job opportunities.

Suitable business models.

A centralized Forestry University for better focus.

One council to govern the entire forestry education, including that in agricultural universities. social forestry, and joint forest management (JFM) schemes and programmes thereof. Interestingly, World Bank has contributed to the promotion of forestry sector in India through a few notable projects ${ }^{16,17}$. In Swaziland, the combined contribution of plantations and the forest products sector to GDP was $12 \%$ between 1988 and 2000, and the forestry sector alone contributes $25 \%$ of that country's foreign exchange earnings ${ }^{18}$. Why are we unable to replicate the same? According to the conservative estimates of World Bank ${ }^{19}$, rural forest incomes in India can rise tenfold from US\$ 222 million in 2004 to about US\$ 2 billion by 2020, if national and state-level amendments are introduced to implement these measures. World Bank has also reported that the forest cover can only be increased with proper management, and communities can increase forest income fivefold by 2020. Undoubtedly, the government is trying its best to improve the status of forestry in the country; the involvement of forestry graduates in these efforts will definitely catalyse the process to a greater extent.

The enactment of the Biodiversity Act and Biodiversity rules of 2002 and 2004, and the National Green Tribunal (NGT) in 2010 are towards strengthening of institutional arrangements to improve the status of forests, biodiversity and the environment. Nevertheless, the significance of forestry education is being overlooked and the potential of forestry graduates is under-utilized. No amicable solution or inclusive roadmap has been prepared to help the forestry graduates. A strength, weakness, opportunity and challenge (SWOC) analysis of forestry education in India identified the weaknesses and challenges, thus calling for transformed policies (Table 1).

With India's commitment to international conventions for reducing carbon emissions, forests and forestry is a significant and/or perennial option that can significantly contribute through effective bioresource management. This too warrants technical personnel with adequate scientific knowledge in forestry.
It is time that we address the future of forestry graduates and bring in some structural changes in the forestry education sector through central ordinance as agriculture is a state subject, while forest is in the concurrent list, indicating that it requires immediate attention of the forest administrators and policy makers. There are three possible ways by which we can address the existing scenario in forestry education in the country.

(i) Enabling a framework policy to recruit preferably forestry students in the state and central forest services, liberal rules for establishment of forest-based start-ups, roll out successful business models along with the provision of lease lands, i.e. wastelands to generate self-employment.

(ii) Forestry education should have curricula input in allied sectors like cultivation of medicinal plants, agroforestry, integrated farming system models, bee-keeping, mushroom cultivation, fishery and sericulture, etc. For instance, the National Agroforestry Policy (2014) envisages that agroforestry has enormous potential to generate employment and about $65 \%$ of the country's timber requirement is met from the trees grown on farmlands. Agroforestry also has the potential to mitigate climate changeby enhanced carbon sequestration, thereby enabling the farmers' climate resilient. Trees on farmlands are uniquely placed for achieving multiple objectives, especially food security, employment, health and nutrition, and ecosystem balance. Provision could be made for forestry graduates as tree inspectors in agroforestry.

(iii) Having a Central Forestry University (CFU) could bring in structural changes for transforming forestry education. All the colleges of forestry presently governed by SAUs could possibly be brought under the regime of one council, be it ICFRE or ICAR, and be affiliated to the CFU to harness uniform tangible and intangible benefits of forestry education. Further, creation of State Forestry Education and Entrepreneurship Cells has been envisaged to provide career counselling for forestry graduates in the country. 
1. http://www.fao.org/docrep/x5356e/x5356e04.htm (accessed on 1 August 2018)

2. Bhat, K. M., Forest education and research in India: country report. For. Sci. Technol., 2005, 1(2), 185-192.

3. Down to Earth, The sad plight of India's forestry graduates, 2016; https://www.downtoearth.org.in/blog/the-sad-plight-of-india-sforest-graduates-53637 (accessed on 31 August 2018).

4. e-Green Watch, List of Forest Divisions Under State and Circles, 2018; http://egreenwatch.nic.in/Masters/Public/DivisionsView-List. aspx (accessed on 10 September 2018).

5. Indira Gandhi National Forest Academy, 2018; http://www. ignfa.gov.in/IndianForestService/tabid/56/language/enUS/Default. aspx (accessed on 5 August 2018).

6. Arunachalam, A. and Arunachalam, K., Socio-economic impact of the ban on timber felling in Arunachal Pradesh, North-Eastern India. Int. J. Ecol. Environ. Sci., 2012, 38(2-3), 119-132.

7. Rangarajan, M., India's Wildlife History: An Introduction, Permanent Black, Delhi in association with the Ranthambore Foundation, 2001.

8. FSI, State of Forest Report, 1987-2017, FSI, Dehraun, http://fsi.nic.in/ (accessed on 10 August 2018).

9. Richards, J. and Flint, E., Historical land use and carbon estimates for South and Southeast Asia, 1880-1980, CDIAC, Oak Ridge, TN, USA, 1994

10. Singh, M. P., Bhojvaid, P. P., Reddy, S. R. and Ashraf, J., Evidences and aspects of forest transition in India. Indian For., 2014 140(8), 737-746.

11. ENVIS, Protected areas of India from 2000 to 2018 (as on July, 2018). ENVIS Centre on Wildlife \& Protected Areas, 2018; http://www.wiienvis.nic.in/Database/Protected_Area_854.aspx (accessed on 10 August 2018).

12. FAO, Protected area management in India: a perspective, 2003; http://www.fao.org/docrep/ARTICLE/WFC/XII/0449-B3.HTM (accessed on 5 August 2018).
13. The Hindu, Forestry students demand job reservation, 2010; https://www.thehindu.com/todays-paper/tp-national/tp-tamilnadu/ Forestry-students-demand-job-reservation/article16482039.ece (accessed on 1 September 2018).

14. The Telegraph, Forestry students shed blood to demand job, 2012; https://www.telegraphindia.com/1120322/jsp/odisha/story_15279063.jsp (accessed on 6 September 2018).

15. Times of India, 2016; https://timesofindia.indiatimes.com/city/ nagpur/Forestry-students-strike-for-reservation-enters-45thday/articleshow/51129653.cms (accessed on 31 August 2016).

16. World Bank, India alleviating poverty through forest development alleviating poverty through Forest Development, 2000; https:// openknowledge.worldbank.org/bitstream/handle/10986/19908/ 207900PUB0REPL0a0ISBN00082130476204.pdf? sequence $=1$ (accessed on 5 September 2018).

17. World Bank, Forests and economic development, 2013; http:// www.worldbank.org/en/topic/forests/brief/forests-and-economic-development (accessed on 3 September 2018)

18. Hassan, R. M., Mbuli, P. and Dlamini, C., Natural resource accounts for the state and economic contribution of forests and woodland resources in Swaziland. Centre for Environmental Economics and Policy in Africa Discussion Paper Series, University of Pretoria, South Africa, 2002, p. 59.

19. World Bank, Overview: the need for forest reform in India, 2006; http://siteresources.worldbank.org/INDIAEXTN/Resources/295583-1143836269232/Overview.pdf (accessed on 6 June 2018).

20. https://www.change.org/p/maharashtra-forest-minister-maharashtra-chief-minister-maharashtra-forest-department-forestrydegree-students-facing-injustice-in-maharashtra-no-jobs-in-forestdepartemnt (accessed on 11 July 2018)

Received 11 September 2018; revised accepted 22 May 2019

doi: $10.18520 / \mathrm{cs} / \mathrm{v} 117 / \mathrm{i} 5 / 748-752$ 